\title{
FUNGI ISOLATED FROM THE EXCRETA OF WILD BIRDS IN SCREENING CENTERS IN PELOTAS, RS, BRAZIL
}

Josiara Furtado MENDES(1), Ana Paula Neuschrank ALBANO(2), Marco Antônio A. COIMBRA(2), Gracialda Ferreira de FERREIRA(2), Carolina Lambrecht GONÇALVES(2), Patrícia da Silva NASCENTE(2) \& João Roberto Braga de MELLO(3)

\begin{abstract}
SUMMARY
The identification of the fungal species belonging to the healthy microflora in animals is a precondition for the recognition of pathological processes causing them. The aim of this study was to investigate the presence of potentially pathogenic fungi in the feces of wild birds collected in Screening Centers. Samples were collected from the feces of 50 cages with different species of birds. The samples were processed according to the modified method STAIB and the plates incubated at $32^{\circ} \mathrm{C}$ for up to ten days with daily observation for detection of fungal growth. The isolation of the following species was observed: Malassezia pachydermatis, Candida albicans, C. famata, C. guilliermondii, C. sphaerica, C. globosa, C. catenulata, C. ciferri, C. intermedia, Cryptococcus laurentii, Trichosporon asahii, Geotrichum klebahnii, Aspergillus spp., A. niger and Penicillium spp. Knowing the character of some opportunistic fungi is important in identifying them, facilitating the adoption of preventive measures, such as proper cleaning of cages, since the accumulation of excreta may indicate a risk for both health professionals and centers for screening public health.
\end{abstract}

KEYWORDS: Birds; Fungi; Excretions.

\section{INTRODUCTION}

Zoonoses transmitted by wild animals kept as pets have been seen as a public health problem. Opportunistic mycoses such as cryptococcosis, aspergillosis, and candidiasis are increasing in their frequency due to immunosuppressive diseases. Moreover, the easy dispersion of spores by wind renders the fungi airborne, causing diseases in humans. Among the opportunistic mycoses that can occur in humans are onychomycosis, otitis, ceratomycoses, and fungemias ${ }^{8}$.

However, the increasing number of conservation programs involving wildlife translocation, release, and reintroduction into their natural environments involves the risk of contagion by the possible transmission of infectious agents to humans ${ }^{5}$. And in this sense, it is estimated that close to fifty million live animals are confined in cages in Brazil, many of them from illegal catches ${ }^{13}$, and they require constant handling.

The opportunistic fungi are generally present in normal microbiota of humans and animals without causing disease processes in healthy individuals, but when a disruption occurs, usually resulting from predisposing factors (pathological, physiological, immunological and mechanical) there is an increase in the invasion and multiplication of these organisms in the tissues, causing infectious conditions ${ }^{11,21}$.

The keeping of wild or exotic animals is a common activity in Brazil; passerines and Psittaciformes are very popular as pets ${ }^{14}$. However, the excreta of these birds represent a source of contamination of domestic and public environments by the species Cryptococcus neoformans, making it a risk factor for the occurrence of cryptococcosis. Aspergillosis is an opportunistic mycosis par excellence, caused by different species of fungi of the genus Aspergillus, especially A. fumigatus ${ }^{3,16}$.

And although the fungal diseases are primarily associated with immunosuppression and inter-current illnesses, understanding the factors involved in the epidemiology of the disease is crucial ${ }^{12}$.

The Centers for Wildlife Screening (CETAS) are places which welcome, identify, triage, treat, and allocate the wild animals rescued or seized by the inspectors, as well as wild animals received from individuals that were holding animals captive in the domicile illegally ${ }^{2}$. Given this context, the aim of this study was to investigate the presence of potentially pathogenic fungi in the feces of wild birds collected at the Center for Rehabilitation of Wild Animals of the Institute of Biology (IB) of the Universidade Federal de Pelotas (UFPEL).

\section{MATERIAL AND METHODS}

Over six months, samples of excreta of birds in 50 cages housed at the Núcleo de Reabilitação da Fauna Silvestre (IB/UFPel) were collected. Five surveys (five cages) were carried out per week from June 2010 to 
MENDES, J.F.; ALBANO, A.P.N.; COIMBRA, M.A.A.; FERREIRA, G.F.; GONÇALVES, C.L.; NASCENTE, P.S. \& MELLO, J.R.B. - Fungi isolated from the excreta of wild birds in screening centers in Pelotas, RS, Brazil. Rev. Inst. Med. Trop. Sao Paulo, 56(6): 525-8, 2014.

July 2011, totaling 50 samples. The bird species that were observed in the NURFS: Saltator aurantiirostris (beak-hard), Pipraeidea bonariensis (Tanager-papa-orange), Stephanophorus diadematus (Basking Tanager), Paroaria coronata (Cardinal Red), Saltator similis (straight rail), Ramphocelus bresilius (tie-blood), Lanio cuculattus (Fret-king), Turdus rufiventris (Rufous-bellied Thrush), Turdus flavipes (thrush-una), Mimus saturninus (Chalk-field), Gubernatrix cristata (Cardinal-yellow) Sicalis flaveola (canary-the-earth), Amblyramphus holosericeus (cardinalthe-plated), Cyanoloxia brissonii (Bluebird), Pitangus sulphuratus (bem-te-vi), Myiopsitta monachus (Monk Parakeet), Ramphastos toco (toucan's black-billed), Guira guira (anu-white) and Columba livia (pigeon-domestic).

The birds are housed in individual cages, and these are organized according to species and families. Usually the animals are housed in the NURFS for a period necessary for recovery. The cages are cleaned daily using the disinfectant chlorhexidine gluconate.

Samples were collected before the daily cleaning of the site, in individual sterile jars, around five grams of feces per cage. The material was immediately sent to the Laboratório de Micologia, Departamento de Microbiologia e Parasitologia, Instituto de Biologia, UFPel for processing.

The excreta samples were processed according to the modified method STAIB ${ }^{10,15}$. In laminar flow, a volume of $1 \mathrm{~g}$ of sample was homogenized with the aid of a mortar and pestle, and was then transferred to a sterile falcon tube with $10 \mathrm{~mL}$ of sterile saline. The tubes were homogenized by vortexing for three min and kept at rest for 30 min until decantation of the supernatant was obtained. Then a dilution was made of each sample by transferring $1 \mathrm{~mL}$ of the supernatant into another sterile falcon tube containing $9 \mathrm{~mL}$ of sterile saline and $5 \mathrm{mg}$ of chloramphenicol (10-1 dilution). The tubes were again homogenized in a vortex and then $100 \mu \mathrm{L}$ aliquots of this solution were seeded in duplicate by scattering technique with the aid of sterile Drigalski loop in Petri dishes containing Sabouraud agar with chloramphenicol and also agar niger (AN). The plates were incubated at $30^{\circ} \mathrm{C}$ for up to seven days with daily observation for detection of fungal growth.

The identification of filamentous fungi was performed from the macro- and micromorphology through visualization of the characteristics of the colonies and the production of blades with visualization Lactophenol blue cotton and carrying microcultive between blades when needed. Yeasts were identified by microscopy with conducting Gram stained smears, technical germ tube, microculture, and biochemical tests using a Vitek 2 system (Table 1).

\section{RESULTS}

Of the 50 samples collected from 50 cages, 45 (90\%) showed some fungal species. In 13 (26\%) samples there was growth of filamentous fungi, 41 (90\%) were isolated from yeast samples, and in ten (20\%) of the samples growth of both filamentous fungi and yeasts occurred.

The following yeast species were observed: Candida albicans (31\%), C. famata (11\%), C. guilliermondii (4\%), C. catenulata (4\%), C. intermedia (2\%), C. sphaerica (4\%), C. ciferri (6\%), Trichosporon asahii (2\%), Rhodotorula sp. (2\%), Geotrichum klebahnii (4\%), Cryptococcus laurentii (4\%), Candida globosa (2\%) and Malassezia pachydermatis
Table 1

Biochemical tests performed by Vitek 2 System for identification of yeasts

\begin{tabular}{|c|c|}
\hline Test & $\begin{array}{c}\text { Quantity/ } \\
\text { well }\end{array}$ \\
\hline L-Lysine ARYLAMIDASE (LysA) & $0.0228 \mathrm{mg}$ \\
\hline L-MALATE assimilation (1MLTa) & $0.15 \mathrm{mg}$ \\
\hline Leucine -ARILAMIDASE (LeuA) & $0.0234 \mathrm{mg}$ \\
\hline GP Arginine (ARG) & $0.15 \mathrm{mg}$ \\
\hline ERYTHRITOL assimilation (ERYa) & $0.3 \mathrm{mg}$ \\
\hline GLYCEROL assimilation (GLYLa) & $0.16 \mu \mathrm{L}$ \\
\hline Tyrosine ARYLAMIDASE (TyrA) & $0.0276 \mathrm{mg}$ \\
\hline BETA-N-ACETYL-GLUCOSAMINIDASE (BNAG) & $0.0408 \mathrm{mg}$ \\
\hline ARBUTIN assimilation (ARBa) & $0.3 \mathrm{mg}$ \\
\hline AMYGDALIN assimilation (AMYa) & $0.3 \mathrm{mg}$ \\
\hline D-GALACTOSE assimilation (dGALa) & $0.3 \mathrm{mg}$ \\
\hline GENTIOBIOSE assimilation (GENa) & $0.3 \mathrm{mg}$ \\
\hline D-GLUCOSE assimilation (dGLUa) & $0.3 \mathrm{mg}$ \\
\hline LACTOSE assimilation (LACa) & $0.96 \mathrm{mg}$ \\
\hline $\begin{array}{l}\text { METHYL-D-GLUCOPYRANOSIDE assimilation } \\
\text { (MAdGa) }\end{array}$ & $0.3 \mathrm{mg}$ \\
\hline D-CELLOBIOSE assimilation (dCELa) & $0.3 \mathrm{mg}$ \\
\hline GAMMA-GLUTAMYL TRANSFERASE (GGT) & $0.0228 \mathrm{mg}$ \\
\hline D-MALTOSE assimilation (dMALa) & $0.3 \mathrm{mg}$ \\
\hline D-RAFFINOSE assimilation dRAFa & $0,3 \mathrm{mg}$ \\
\hline PNP-N-acetyl-BD-galactosaminidase (1 NAGA1) & $0.0306 \mathrm{mg}$ \\
\hline D-MANNOSE assimilation (dMNEa) & $0.3 \mathrm{mg}$ \\
\hline D-MELIBIOSE assimilation (dMELa) & $0.3 \mathrm{mg}$ \\
\hline D-MELEZITOSE assimilation (dMLZa) & $0.3 \mathrm{mg}$ \\
\hline L-SORBOSE assimilation (1SBEa) & $0.3 \mathrm{mg}$ \\
\hline L-RHAMNOSE assimilation (IRHAa) & $0.3 \mathrm{mg}$ \\
\hline XYLITOL assimilation (XLTa) & $0.3 \mathrm{mg}$ \\
\hline D-SORBITOL assimilation (dSORa) & $0.1875 \mathrm{mg}$ \\
\hline SUCROSE / SUCROSE assimilation (SACa) & $0.3 \mathrm{mg}$ \\
\hline UREASE (URE) & $0.15 \mathrm{mg}$ \\
\hline ALPHA-GLUCOSIDASE (AGLU) & $0.036 \mathrm{mg}$ \\
\hline D-TURANOSE assimilation (dTURa) & $0.3 \mathrm{mg}$ \\
\hline D-TREHALOSE assimilation (dTREa) & $0.3 \mathrm{mg}$ \\
\hline NITRATE assimilation (NO3a) & $0.03 \mathrm{mg}$ \\
\hline L-ARABINOSE assimilation (1ARAa) & $0.3 \mathrm{mg}$ \\
\hline D-GALACTURONATE assimilation (dGATa) & $0.15 \mathrm{mg}$ \\
\hline ESCULIN hydrolysis (ESC) & $0.225 \mathrm{mg}$ \\
\hline L-GLUTAMATE assimilation (1GLTa) & $0.15 \mathrm{mg}$ \\
\hline D-XYLOSE assimilation (dXYLa) & $0.3 \mathrm{mg}$ \\
\hline DL-LACTATE assimilation (LATa) & $0.15 \mathrm{mg}$ \\
\hline ACETATE assimilation (ACEa) & $0.15 \mathrm{mg}$ \\
\hline CITRATE assimilation (SODA) (CITa) & $0.15 \mathrm{mg}$ \\
\hline GLUCURONATE assimilation (GRTas) & $0.15 \mathrm{mg}$ \\
\hline L-PROLINE assimilation (IPROa) & $0.15 \mathrm{mg}$ \\
\hline 2-KETO-D-GLUCONATE assimilation (2KGa) & $0.15 \mathrm{mg}$ \\
\hline ACETYL GLUCOSAMINE assimilation (NAGa) & $0.15 \mathrm{mg}$ \\
\hline D-GLUCONATE assimilation (dGNTa) & $0.15 \mathrm{mg}$ \\
\hline
\end{tabular}




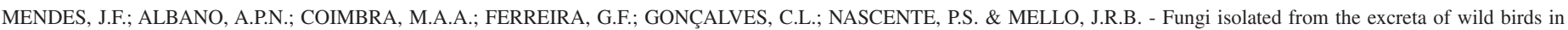
screening centers in Pelotas, RS, Brazil. Rev. Inst. Med. Trop. Sao Paulo, 56(6): 525-8, 2014.

(2\%), and also the following filamentous genera: Aspergillus spp. (8\%), A. niger (4\%), Penicillium spp. (6\%) and Mucor sp. (4\%).

Among the birds of the family Thraupidae (Saltator aurantiirostris, Pipraeidea bonariensis, Stephanophorus diadematus, Paroaria coronate, Saltator similis, Ramphocelus bresilius, Lanio cuculattus) the following growth of yeast was observed (Chart 1): M. pachydermatis Rhodotorula sp., C. laurentii, G. klebahnii, C. globosa., C. famata, C. albicans, C. guilliermondii, $C$. sphaerica, and $C$. catenulata, and the following intermediate filamentous fungus: Aspergillus sp., Pennicilium sp. and Mucor sp.

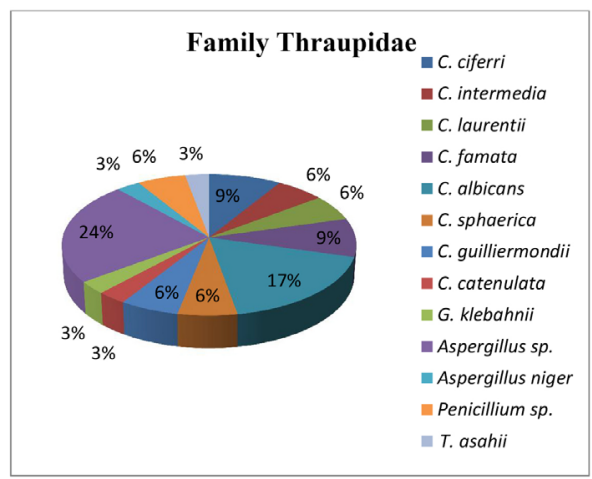

Chart 1 - Fungi isolated in Family Thraupidae.

As for the family Turdidae (Chart 2): Turdus rufiventris and Turdus flavipes the following was found: the filamentous fungus A. niger and the yeasts G. klebahnii, C. albicans C. ciferri.

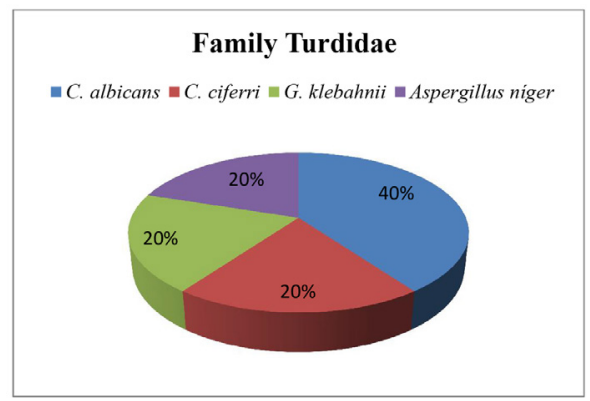

Chart 2 - Fungi isolated in Family Turdidae.

In the Amblyramphus holosericeus, family Icteridae Pennicilium sp. and the yeast $C$. catenulata were isolated. In the Cyanoloxia brissonii family Cardinals found Mucor sp. and C. albicans. In Cuculidae (Guira guira): C. albicans and Rhodotorula sp. (Charts 3, 4 and 5).

In the family Tirannidae (Pitangus sulphuratus), in Psittacidae (Myiopsitta monachus), Emberizidae (Gubernatrix cristata and Sicalis flaveola) and Ramphastidae (Ramphastos vitellinus) there were only isolated strains of C. albicans, as in Mimidae (Mimus saturninus). Finally, in Columbidae (Columba livia), there was no fungal growth.

\section{DISCUSSION}

The fragmentation and degradation of habitats, the isolation of

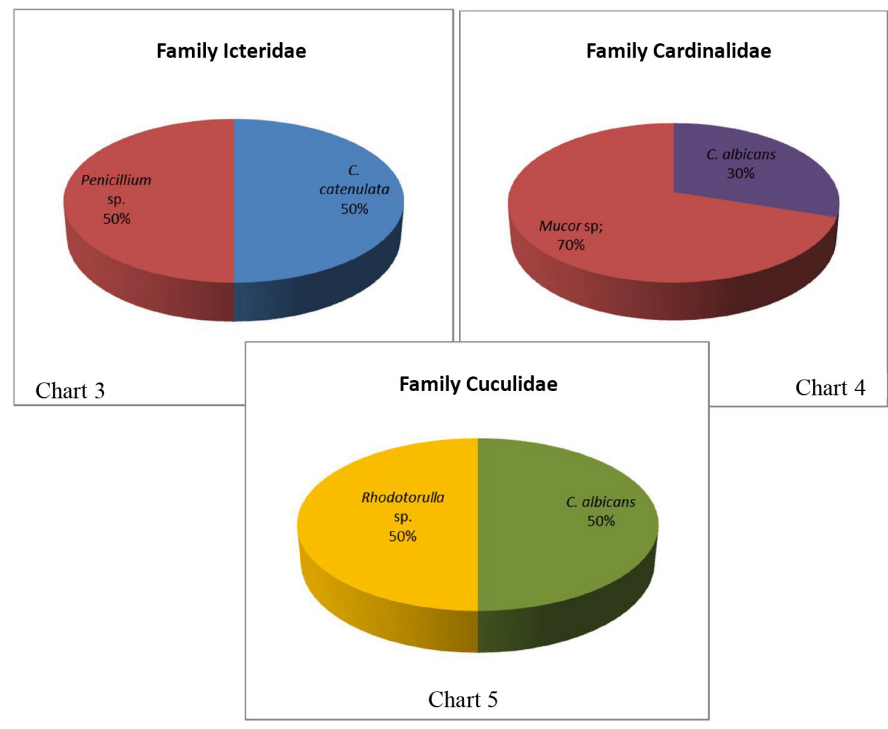

Charts 3, 4 and 5 - Fungi isolated in Families Icteridae, Cardinals and Cuculidae.

populations, and greater proximity to humans and their pets has hampered the health of wild animals ${ }^{6}$. Furthermore, animals held in captivity or transported even for a short period can be exposed to a variety of pathogens, and become potential carriers of infectious diseases ${ }^{1}$.

From an epidemiological standpoint, poultry birds have an especially important role in contamination of the environment and the spread of pathogens by depositing their excreta. The behavior of birds frequently approaching the population as they are searching for food and shelter, contributes to the transmission of human pathogens, such as fungi and parasites $^{19}$. C. neoformans is common in pigeon excreta, as can be seen in FARIA et al. (2010), but were negative in this experiment, justified by the low number of specimens of the species. Cryptococcus sp. passerines in the study ${ }^{12}$ have also been found. SANTOS et al. (2009), isolated $C$. neoformans and Candida spp. in the feces of captive parrots and passerines.

Yeasts and moulds now rank among the ten most frequently isolated pathogens in febrile patients with an impaired immune system. Fungi are mainly opportunistic pathogens that only invade the body if a severely weakened natural defense permits them to do so. Most factors facilitating an invasive fungal infection are unavoidable because they are directly connected to the underlying diseases as well as to their treatment ${ }^{11,21}$.

The relevance of avian zoonoses is that, being asymptomatic infections in birds that are wrongly viewed as healthy, they hinder a possible diagnosis and treatment, thus increasing the chances of transmission to owners ${ }^{12}$. Maintenance of hygiene on the premises, wearing rubber gloves so that there is no direct contact with excreta, washing and sanitizing hands thoroughly after contact and handling of the birds are key practices to avoid possible transmission of zoonoses ${ }^{17}$.

The fungi, such as Aspergillus spp., are ubiquitous and airborne in the environment; they are microorganisms classified among the most abundant, and globally distributed, and can be isolated from soil, air, water, foods, plants, and the surfaces of decomposing material ${ }^{20,23}$. The main clinical form of aspergillosis in birds is the respiratory one, and the 
MENDES, J.F.; ALBANO, A.P.N.; COIMBRA, M.A.A.; FERREIRA, G.F.; GONÇALVES, C.L.; NASCENTE, P.S. \& MELLO, J.R.B. - Fungi isolated from the excreta of wild birds in screening centers in Pelotas, RS, Brazil. Rev. Inst. Med. Trop. Sao Paulo, 56(6): 525-8, 2014.

infectious source, Aspergillus conidia from the environment, penetrates into the host organism mainly by air, thus affecting the respiratory system of these animals ${ }^{10}$.

The fungi found in this study are known to be potentially infectious pathogens by characteristics such as their ability to produce enzymes, adhesion capacity to the host cell, resistance to antifungal agents, and are associated with the production of hyphas that may contribute to the infectious process ${ }^{9,22}$.

With regard to hygiene and health, it is essential to remove the feces and urine of animals in captivity daily, preventing the proliferation of bacteria and fungus in the environment. Perches and nests should be free of droppings; drinking and feeding troughs should not be located beneath the perches so that the birds do not defecate in them. Cages must be washed and brushed every day and disinfected frequently. In this sense, it can be seen that cleaning, sanitizing, and disinfection are critical in maintaining any captivity. In the study area, the cages, drinkers, feeders, bowls, perches, nests, and even the utensils and equipment were cleaned daily; however a high percentage of organisms that are potentially pathogenic to humans and animals ${ }^{4}$ were still observed.

Potentially pathogenic fungi are present in the feces of wild birds housed in rehabilitation centers and could pose risks to human health and animals. Thus, care with cleaning, sanitizing, and disinfecting are critical in maintaining any captivity.

\section{RESUMO}

\section{Fungos isolados de excretas de aves silvestres em centro de reabilitação em Pelotas, RS, Brasil}

A identificação das espécies de fungos pertencentes à microbiota saudável em animais é pré-condição para o reconhecimento dos processos patológicos causados por esses. O objetivo deste estudo foi investigar a presença de fungos potencialmente patogênicos nas fezes de aves selvagens coletadas em Centros de Triagem. Foram coletadas amostras de fezes de 50 gaiolas com diferentes espécies de aves. As amostras foram processadas de acordo com o método modificado STAIB e as placas foram incubadas a $32{ }^{\circ} \mathrm{C}$ por até dez dias, com observações diárias para detecção do crescimento dos fungos. Observamos o isolamento de espécies: Malassezia pachydermatis, Candida albicans, C. famata, C. guilliermondii, C. sphaerica, C. globosa, C. catenulata, C. ciferri, C. intermedia, Cryptococcus laurentii, Trichosporon asahii, Geotrichum klebahnii, Aspergillus spp., A. niger e Penicillium spp. Conhecendo o caráter de alguns fungos oportunistas resalta-se a importância para identificá-los, facilitando a adoção de medidas preventivas, como a limpeza adequada das gaiolas, uma vez que a acumulação de excrementos pode indicar um risco tanto para os profissionais de saúde e centros de triagem de saúde pública.

\section{REFERENCES}

1. Baker LR, Soorae PS, editors. Re-introduction NEWS. 2002. Newsletter of the ReIntroduction Group of IUCN's Species Survival Commission. Special Primate Issue No. 21. 60p. (ISSN 1560-3709). Available from: http://www.iucnsscrsg.org/ STORAGE/RSG\%20CD/14th/PDFs/RNews21.pdf

2. Brasil. IBAMA. Centros de triagem de animais silvestres - CETAS. 2008. [cited 2011 Nov 20]. Available from: http://www.ibama.gov.br/fauna.
3. Clarke J, Kerry KP. Diseases and parasites of penguins. Korean J Polar Res. 1993;4:79-96.

4. Cubas ZS. Papagaio: saiba mais sobre eles. Saúde Animal; 2009. [cited 2011 Jul]. Available from: http://www.saudeanimal.com.br

5. Cunningham AA. Disease risks of wildlife translocations. Conservation Biol. 1996;10:349 53.

6. Daszak P, Cunningham AA, Hyatt AD. Emerging infectious disease of wildlife: threat to biodiversity and human health. Science. 2000;287(5452):443-9.

7. Faria RO, Nascente PS, Meinerz ARM, Cleff MB, Antunes TA, Silveira ES, et al Ocorrência de Cryptococcus neoformans em excretas de pombos na cidade de Pelotas, Estado do Rio Grande do Sul. Rev Soc Bras Med Trop. 2010;43:198-200.

8. Jawets E. Micologia médica. 20a ed. Rio de Janeiro: Guanabara Koogan; 1998.

9. Lacaz CS, Porto E, Martins JEC, Heins-Vaccari EM, Melo NT. Tratado de micologia médica. $9^{a}$ ed. São Paulo: Sarvier; 2002.

10. Machado CC, Amaral AA, Severo LC. Cryptococcus neoformans var. neoformans isolado do solo. Rev Inst Med Trop Sao Paulo. 1993;35:77-9.

11. Matos BM, Komiyana EY, Balducci I, Koga-Ito CY. Atividade antifúngica do extrato alcoólico de Mentha piperita sobre Candida albicans e C. tropicalis. Rev Odonto UNESP (Araraquara). 2009;38:244-8.

12. Mancianti F, Nardoni S, Ceccherelli R. Occurrence of yeasts in psittacine droppings from captive birds in Italy. Mycopathologia. 2002;153:121-4.

13. Marinho M, Táparo CV, Silva BG, Tencate LN, Perri SLV. Microbiota fúngica de passeriformes de cativeiros da região noroeste do Estado de São Paulo. Vet Zootec. 2010;17:288-92.

14. Melo NT, Nigro NTM, Pereira AD, Huggins DW, Lacaz CS. Isolamento de Cryptococcus neoformans de fezes de pombos, do solo e ninhos de pombos. Rev Bras Med. 1987:44:19-23.

15. Moreira V. IAP apreende animais em cativeiro. Folha de Londrina. [Cited 2013 Jan 15]. Available from: http://www.folhaweb.com.br/?id_folha=2-1-117\&id_ origem $=2-1--5743-20000118$.

16. Queiroz JPAF, Sousa FDN, Lage RA, Izael MA, Santos AG. Criptococcose: uma revisão bibliográfica. Acta Vet Bras. 2008;2:32-8.

17. Ritchie BW, Harrison GJ, Harrison LR. Avian Medicine: principles and application Florida: Wingers; 1994. p. 1000-4

18. Santos LL, Ferreira FM, Lopes SF, Condas LA, Muro MD, Lugarini C. Pesquisa de Cryptococcus neoformans e Candida spp. em excretas de psitacídeos e passeriformes cativos. Arq Cienc Vet Zool Unipar. 2009;12:5-9.

19. Schüller M. Pesquisa de protozoários e helmintos de interesse médico presentes nas excretas do pombo doméstico Columba livia domestica. [Dissertação]. São Paulo: Universidade de São Paulo, Faculdade de Saúde Pública; 2004

20. Sidrim JJC, Rocha MFG. Micologia Médica à luz de autores contemporâneos. Rio de Janeiro: Guanaba Koogan; 2004

21. Suzuki LC. Desenvolvimento de um biofilme formado por Candida albicans in vitro para estudo da terapia fotodinâmica. [Dissertação]. São Paulo: Universidade de São Paulo: Instituto de Pesquisas Energéticas Nucleares; 2009

22. Taylor BN, Staib P, Binder A, Biesemeier A, Sehnal M, Röllinghoff M, et al. Profile of Candida albicans-secreted aspartic proteinase elicited during vaginal infection. Infect Immun. 2005;73:1828-35.

23. Ward OP, Qin WM, Dhanjoon J, Ye J, Singh A. Physiology and biotechnology of Aspergillus. Adv Appl Microbiol. 2005;58:1-75.

Received: 3 September 2013

Accepted: 6 May 2014 